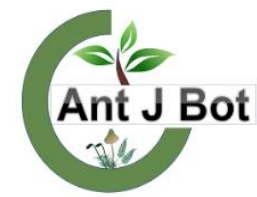

\title{
Antioxidant potential of Pseudevernia furfuracea (L.) Zopf and its secondary metabolites on hepatocellular carcinoma cells: regulation of antioxidant enzymes
}

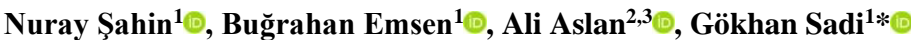 \\ ${ }^{1}$ Karamanoğlu Mehmetbey University, Kamil Özdağ Science Faculty, Dept. of Biology, Karaman, Turkey \\ ${ }^{2}$ Van Yüzüncü Yll University, Pharmacy Faculty, Department of Pharmacology, Van, Turkey \\ ${ }^{3}$ Kyrgyz-Turkish Manas University, Science and Arts Faculty, Department of Biology, Bishkek, Kyrgyzstan \\ *sadi.gokhan@gmail.com,n.gursoy19@gmail.com,bemsen@kmu.edu.tr, aliaslan@yyu.edu.tr
}

Received : 10.09.2021

Accepted : 25.09.2021

Online $\quad: 02.11 .2021$

\section{Pseudevernia furfuracea (L.) Zopf ve sekonder metabolitlerinin hepatosellüler karsinom hücreleri üzerindeki antioksidan potansiyeli: antioksidan enzimlerin düzenlenmesi}

\begin{abstract}
The use of medicinal plants and secondary metabolites increases in treating numerous diseases such as hepatocellular carcinoma (HCC), one of the leading causes of cancer-related death worldwide. Oxidative stress contributes to the development of liver cancer, and promoting antioxidant systems might provide better insights for the treatment. In the present study, the antioxidant potential of Pseudevernia furfuracea (L.) Zopf lichen species were investigated. Besides, effects of major secondary metabolites, olivetoric acid (OA) and physodic acid (PA), which were isolated from P. furfuracea, on hepatic gene expressions of antioxidant enzymes, were evaluated in both cancerous (HepG2) and healthy (THLE2) human liver cells. According to the results, the total phenolic content of $P$. furfuracea was $71.52 \mu \mathrm{g} / \mathrm{mg}$ and $8.16 \mu \mathrm{g} / \mathrm{mg}$ gallic acid equivalent for ethanolic and aqueous extracts, respectively. Likewise, $\beta$-carotene and lycopene contents were also higher in ethanolic extracts. In line with these antioxidant ingredients, DPPH (2,2-diphenyl-1-picrylhydrazyl) radical scavenging activity of ethanol extract (IC50: 158.79 $\mathrm{mg} / \mathrm{L}$ ) was remarkably high as compared with its aqueous extracts (IC50: $630.33 \mathrm{mg} / \mathrm{L}$ ). OA and PA strongly augment all antioxidant enzymes' gene expressions in HepG2 cells, while only gpx expression was upregulated in healthy THLE2 cells. Conversely, these two metabolites suppress cat, sodl, and sod 2 expressions in THLE2 cells. These results together suggest that $P$. furfuracea not only has high antioxidant potential, but its secondary metabolites might also reduce oxidative stress in cancer cells by upregulating antioxidant enzymes, which would prevent oncogenesis and tumor progression in liver cancer.
\end{abstract}

Keywords: Pseudevernia furfuracea, olivetoric acid, physodic acid, antioxidant potential, antioxidant enzymes

\begin{abstract}
Özet: Dünyada kansere bağlı ölümlerin önde gelen nedenlerinden biri olan hepatosellüler karsinom (HCC) gibi çok sayıda hastalığın tedavisinde tıbbi bitkilerin ve sekonder metabolitlerin kullanımı artmaktadır. Oksidatif stres, karaciğer kanseri gelişimine katkıda bulunur ve antioksidan sistemlerin teşvik edilmesi, tedavi için daha iyi bilgiler sağlayabilir. Bu çalışmada, Pseudevernia furfuracea (L.) Zopf likeninin antioksidan potansiyeli araştırılıştır. Ayrıca, P.furfuracea'dan izole edilen ana sekonder metabolitler olan olivetorik asit (OA) ve fisodik asitin (PA) hepatik antioksidan enzimlerin gen ekspresyonları üzerindeki etkileri hem kanserli (HepG2) hem de sağlıklı (THLE2) insan karaciğer hücrelerinde değerlendirilmiştir. Sonuçlara göre, $P$. furfuracea'nın toplam fenolik içeriği etanolik ve sulu ekstraktlar için sırasıyla $71.52 \mu \mathrm{g} / \mathrm{mg}$ ve $8.16 \mu \mathrm{g} / \mathrm{mg}$ gallik asit eşdeğeri bulunmuștur. Aynı șekilde $\beta$-karoten ve likopen içerikleri de etanolik ekstraktlarda daha yüksek olarak belirlenmiștir. $\mathrm{Bu}$ antioksidan bileşenlerle uyumlu olarak, etanol özütünün DPPH (2,2-difenil-1-pikrilhidrazil) radikal süpürme aktivitesi (IC 50 : $158.79 \mathrm{mg} / \mathrm{L}$ ), sulu ekstraktlar ( $\mathrm{IC}_{50}: 630.33 \mathrm{mg} / \mathrm{L}$ ) ile karşılaştırıldığında oldukça yüksektir. OA ve PA, HepG2 hücrelerinde tüm antioksidan enzimlerin gen ifade düzeylerini arttırırken, sağlıklı THLE2 hücrelerinde ise sadece gpx ekspresyonu yukarı yönde regüle olmuştur. Bundan farklı olarak, her iki metabolit de THLE2 hücrelerinde cat, sodl ve sod2 ekspresyonlarını baskılamıştır. Bu sonuçlar $P$. furfuracea'nın sadece yüksek antioksidan potansiyeline sahip olmadı̆̆ını, aynı zamanda sekonder metabolitlerinin de karaciğer kanserinde onkogenezi ve tümör ilerlemesini önleyecek antioksidan enzimleri yukarı regüle ederek kanser hücrelerinde oksidatif stresi azaltabileceğini göstermektedir.
\end{abstract}

Anahtar Kelimeler: Pseudevernia furfuracea, olivetorik asit, fisodik asit, antioksidan potansiyeli, antioksidan enzimler

Citation: Şahin N, Emsen B, Aslan A, Sadi G (2021). Antioxidant potential of Pseudevernia furfuracea (L.) Zopf and its secondary metabolites on hepatocellular carcinoma cells: regulation of antioxidant enzymes. Anatolian Journal of Botany 5(2): 127-133.

\section{Introduction}

Hepatocellular carcinoma (HCC) is one of the most lethal cancer types worldwide, and accumulating evidence has pointed to the association between oxidative stress and the development of HCC; however, the mechanisms and overall impacts remain uncertain ( $\mathrm{Fu}$ and Chung, 2018). Under normal physiological conditions, antioxidant enzymes play significant roles against oxidative stress. Among them, cytosolic (SOD1) and mitochondrial superoxide dismutase (SOD2) act on superoxide radicals to produce hydrogen peroxide that would eventually be detoxified by catalase (CAT) and glutathione peroxidase
(GPx) enzymes. In addition to endogenous antioxidants in cells, exogenous antioxidants from natural species and secondary metabolites would protect cells against oxidative stress. Among the antioxidant compounds, especially phenolics have high capacities to act on radicals. Phenolic compounds have many different types, such as gallic acid, rutin, phloridzin, syringic acid, ferulic acid, and almost all of them show very high antioxidant properties (Mohammed et al., 2020; Emsen and Kolukisa, 2021). Many different plant species containing these compounds have traditionally been used by the public to treat diseases and are still highly preferred, especially in Asian countries (Bailly, 2021; 
Bharti et al., 2021; Wang et al., 2021). Medicinal and aromatic plants can show different activities thanks to the various metabolites they contain (Ameh et al., 2010; Mohammed et al., 2021; Pachi et al., 2020).

Lichens have traditional uses dating back to ancient times. These organisms came into being by the symbiotic association of fungi and algae (Zambare and Christopher, 2012; Korkmaz et al., 2018). The presence of two different organisms in the structures of lichens contributes to the production of metabolites that are not found in other living organisms. Especially, secondary metabolites and extracts produced by lichens have the potential to show many biological activities (Ranković and Kosanić, 2019). Properties such as anticancer (Solárová et al., 2020a), genoprotective (Turkez et al., 2014), antiviral (Karagöz and Aslan, 2005), antifungal (Karabulut and Ozturk, 2015), antioxidant (Emsen, 2019), and antibacterial (Shrestha et al., 2014) reveal the different potentials of lichens. Pseudevernia furfuracea (L.) Zopf is a fruticose lichen that has been preferred in both traditional, alternative and complementary treatment processes since ancient times. Many different biological activities of this species are available in the literature (Ranković and Kosanić, 2019). Antioxidant, antimicrobial, anticancer (Kosanić et al., 2013), antifungal (Karabulut and Ozturk, 2015), proapoptotic (Šeklić et al., 2018), anti-inflammatory (Güvenç et al., 2012), and antibiofilm (Mitrović et al., 2014) activities are some of the major effects determined with $P$. furfuracea.

Olivetoric acid (OA) and physodic acid (PA) are the two primary secondary metabolites obtained from the lichen species, and they strongly improve the total antioxidant capacities of hepatic cells in vitro (Emsen et al., 2020; Emsen et al., 2021). Previously, we evaluated the apoptotic/necrotic impacts, cytotoxic, oxidative, antioxidative, genotoxic, and antigenotoxic effects of these secondary metabolites on the cancerous human liver (HepG2) and healthy human liver (THLE2) cell lines. However, the overall antioxidant potential of $P$. furfuracea and the effects of secondary metabolites over endogenous antioxidant enzymes remains to be elucidated. Therefore, this study is designed to evaluate the antioxidant potential of $P$. furfuracea by examining total phenolic contents, $\beta$ carotene, and lycopene contents, DPPH free radical scavenging activities together with metal chelating power. Additionally, the regulatory roles of secondary metabolites isolated from $P$. furfuracea over hepatic antioxidant enzymes; CAT, SOD1, SOD2, and GPx were evaluated in both cancerous (HepG2) and non-cancerous (THLE2) cells at the gene expression level.

\section{Materials and Method}

\subsection{Lichen samples}

Pseudevernia furfuracea samples were collected from the Oltu region of Erzurum province of Turkey. Samples were photographed in their natural environment and were carried to the laboratory and air-dried. To identify lichens, macroscopic and microscopic data were utilized using the published literature (Purvis et al., 1992; Wirth, 1995).

\subsection{Preparation of the extracts and isolation of} olivetoric and physodic acid

The lichen specimens were dried under room conditions and powdered with an ultra-centrifuge grinder (Retsch ZM 200,
Germany). Then, ethanol and water extracts of $P$. furfuracea were obtained by $250 \mathrm{~mL}$ solvent systems using Soxhlet extraction apparatus. After filtering through Whatman No. 1 filter paper, the solvent was evaporated with a rotary evaporator and then lyophilized. OA and PA were isolated from $P$. furfuracea as we described in detail previously (Emsen et al., 2020; Emsen et al., 2021) using Soxhlet extraction and then silica column chromatography. The chemical structures of OA and PA were determined by proton and carbon-13 nuclear magnetic resonance spectrum.

\subsection{Free radical scavenging activity of $P$. furfuracea}

In measuring 2,2-diphenyl-1-picrylhydrazyl (DPPH) scavenging activity of ethanol and water extracts obtained from $P$. furfuracea, applications were carried out with the final concentrations of the extracts in the plate wells of 200, 400, 600, 800, and $1000 \mathrm{mg} / \mathrm{L}$. According to the method, 20 $\mu \mathrm{L}$ of the extracts were placed in each microplate well, and $180 \mu \mathrm{L}$ of DPPH $(0.06 \mathrm{mM}$ in methanol) was added. The reduction of DPPH free radical was determined by measuring the absorbance values at $517 \mathrm{~nm}$ after $60 \mathrm{~min}$ incubation in the dark. The free radical scavenging activities of the extracts were calculated as a percentage using the following formula: Radical scavenging activity $=[($ Control absorbance - Extract absorbance) / Control absorbance) $] \times$ 100 .

\subsection{Metal chelating activity of $\boldsymbol{P}$. furfuracea}

In the measurement of the metal chelating activity of ethanol and water extracts, applications were carried out with the final concentrations of the extracts in the plate wells of 200, 400, 600, 800, and $1000 \mathrm{mg} / \mathrm{L}$. According to the method, $50 \mu \mathrm{L}$ of the extracts were added to each microplate well. $10 \mu \mathrm{L}$ of ferrozine $(5 \mathrm{mM}), 5 \mu \mathrm{L}$ of $\mathrm{FeCl}_{2}$ ( $2 \mathrm{mM})$, and $185 \mu \mathrm{L}$ of methanol were added and kept at room temperature for $10 \mathrm{~min}$. Spectrophotometric measurements were performed at $562 \mathrm{~nm}$. The metal chelating activities of the extracts were calculated in percentage with the following formula: Metal chelating activity $=[($ Control absorbance - Extract absorbance $) /$ Control absorbance) $] \times 100$.

\subsection{Determination of total phenolic content of $P$. furfuracea}

In the process of determining the total phenolic contents of ethanol and water extracts from $P$. furfuracea, gallic acid $(0.01,0.05,0.1,0.2,0.4,0.5,1.0 \mathrm{mM})$ was used as a standard. $20 \mu \mathrm{L}$ of ethanol and water extracts and standards up to a concentration of $1000 \mathrm{mg} / \mathrm{L}$ were added in the microplate wells. $20 \mu \mathrm{L}$ of Folin reagent $(2 \mathrm{~N})$ was applied, and the samples mixed by pipetting were incubated in the dark for $3 \mathrm{~min}$. Then, $20 \mu \mathrm{L}$ of $35 \%(\mathrm{w} / \mathrm{v})$ sodium carbonate and $140 \mu \mathrm{L}$ of $\mathrm{dH}_{2} \mathrm{O}$ were added and kept in the dark for 10 min. Spectrophotometric reading was performed at $725 \mathrm{~nm}$. Calculation in gallic acid equivalents was performed using the standard calibration curve.

\subsection{Determination of $\beta$-carotene and lycopene content}

The amounts of $\beta$-carotene and lycopene in ethanol and water extracts obtained from $P$. furfuracea were determined spectrophotometrically. According to the method, $1 \mathrm{~mL}$ of the extracts was mixed with $1 \mathrm{~mL}$ of acetone:hexane (4:6) and filtered through a filter paper after vortexing. Then, the amounts of $\beta$-carotene and lycopene were calculated using 
the absorbance values at 453,505 , and $663 \mathrm{~nm}$ wavelengths, according to the following formulas:

$\beta$-carotene content $(\mathrm{mg} / 100 \mathrm{mg})=0.216 \times$ Absorbance $(663$ $\mathrm{nm})-0.304 \times$ Absorbance $(505 \mathrm{~nm})+0.452 \times$ Absorbance $(453 \mathrm{~nm})$

Lycopene content $(\mathrm{mg} / 100 \mathrm{mg})=-0.0458 \times$ Absorbance $(663 \mathrm{~nm})+0.372 \times$ Absorbance $(505 \mathrm{~nm})-0.0806 \times$ Absorbance (453 nm)

\subsection{Culture of the THLE2 and HepG2 cells}

This study evaluated the effects of $P$. furfuracea secondary metabolites; OA and PA on normal human hepatocytes (THLE2) and human hepatocellular carcinoma (HepG2) cells. THLE2 cells were cultured in Bronchial Epithelial Cell Growth Medium (BEGM) enriched with gentamycin/ amphotericin, epinephrine, phosphoethanolamine, 10\% fetale bovine serum (FBS) and epidermal growth factor (Lonza, Clonetics Corporation, Walkersville, MD 21793 (BEGM Bullet Kit)). HepG2 cells were grown in high glucose-containing Dulbecco's Modified Eagle Medium (DMEM) supplemented with $10 \%$ FBS and standard antibiotics (1\% penicillin/streptomycin) in an incubator (Sanyo MCO $17 \mathrm{AIC}, \mathrm{USA}$ ) at $37^{\circ} \mathrm{C}$ under $95 \%$ humidity and $5 \% \mathrm{CO}_{2}$ concentration. The cells were subcultured to their new growth media after reaching around 90\% confluency. We determined the cell growth inhibitory potential of both OA and PA on THLE2 and HepG2 cells, previously (Emsen et al., 2020; Emsen et al., 2021).

2.8. Total RNA isolation and evaluation of antioxidant genes' expression profiles

HepG2 and THLE2 cells $\left(1 \times 10^{+6}\right.$ cells/well) were treated with $200 \mathrm{mg} / \mathrm{L}$ of OA and PA for 72-h. The dose of OA and PA were determined according to the median inhibitory concentration $\left(\mathrm{IC}_{50}\right)$ values that we published previously (Emsen et al., 2020; Emsen et al., 2021). After application, the cells were detached, and total RNAs were isolated with a miRNeasy RNA isolation kit (Qiagen, USA). Qubit 4.0 fluorometer (Thermo, USA) was utilized to evaluate the quality and quantity of isolated RNAs. Then, two $\mu \mathrm{g}$ of total RNA were reverse transcribed (First-strand cDNA synthesis kit, Thermo Scientific, USA) as described in the manufacturer protocol. Expression levels of antioxidant genes were determined with qRT-PCR (Light Cycler480 II, Roche, Switzerland). For gene expression measurements, 1 $\mu \mathrm{L}$ of cDNA were mixed with $5 \mu \mathrm{L}$ SYBR Green Reaction Mix (Roche, Basel, Switzerland) and $4 \mu \mathrm{L}$ primer pairs (Table 1 ) at $0.5 \mu \mathrm{M}$ concentrations each in the final volume. qPCR reaction was initiated with $95{ }^{\circ} \mathrm{C}$ incubation for 10 min. Then 40-repeated cycles of $95{ }^{\circ} \mathrm{C}$ for $10 \mathrm{~s}$ for denaturation, $58^{\circ} \mathrm{C}$ for $15 \mathrm{~s}$ for annealing, and $72{ }^{\circ} \mathrm{C}$ for 15 for extension were conducted. Green fluorescence values were measured at the end of each extension step, and a melt analysis was performed to confirm the unity of qPCR products. The relative expression of antioxidant enzymes with respect to the housekeeping gene (gapdh) was calculated with the advance relative quantification tool of LightCycler II 480 SW 1.5.1 software (Roche, Basel, Switzerland).
Table 1. Primer sequences of genes used in qPCR studies.

\begin{tabular}{rll}
\hline Gene & & Primer sequences $\left(\mathbf{5}^{\prime} \rightarrow \mathbf{3}\right.$ ') \\
\hline \multirow{2}{*}{$\boldsymbol{c a t}$} & Forward & GAACAGATAGCCTTCGACCC \\
\cline { 2 - 3 } & Reverse & AGTAATTTGGAGCACCACCC \\
\hline \multirow{2}{*}{$\boldsymbol{p} \boldsymbol{x}$} & Forward & CAGTCGGTGTATGCCTTCTC \\
\cline { 2 - 3 } & Reverse & TTCTTGGCGTTCTCCTGATG \\
\hline \multirow{2}{*}{$\boldsymbol{s o d 1}$} & Forward & AGATGACTTGGGCAAAGGTG \\
\cline { 2 - 3 } & Reverse & TTGGGCGATCCCAATTACAC \\
\hline \multirow{2}{*}{$\boldsymbol{s o d} \mathbf{2}$} & Forward & GCACATTAACGCGCAGATCA \\
\cline { 2 - 3 } & Reverse & AGCCTCCAGCAACTCTCCTT \\
\hline \multirow{2}{*}{$\boldsymbol{g a p d h}$} & Forward & CTTCTTTTGCGTCGCCAGCC \\
\cline { 2 - 3 } & Reverse & TGGAATTTGCCATGGGTGGA \\
\hline
\end{tabular}

\subsection{Statistical analyses}

All data were analyzed with one-way ANOVA followed by the appropriate post-hoc test, the Duncan test. Probit regression analysis was used to calculate the median inhibitor concentration $\left(\mathrm{IC}_{50}\right)$ values. All analyses were done using SPSS 21.0 software (IBM Corporation, Armonk, NY, USA).

\section{Results}

\subsection{DPPH scavenging activity of $P$. furfuracea}

For DPPH scavenging activity, a concentration-dependent increase was detected for both ethanol and water extracts. 800 and $1000 \mathrm{mg} / \mathrm{L}$ concentrations of the ethanol extract showed activity over $95 \%$, and the difference between the two values was statistically $(p>0.05)$ insignificant. Similarly, there was no statistical $(p>0.05)$ difference between the concentrations mentioned above of the water extract. However, the highest DPPH activity of the water extract was $62.70 \%$ (Figure 1). The $\mathrm{IC}_{50}$ value of the ethanol extract $(158.79 \mathrm{mg} / \mathrm{L})$ was lower than the water extract $(630.33 \mathrm{mg} / \mathrm{L})$ (Table 1). Considering these results, it is clear that the DPPH scavenging activity of the ethanol extract was higher than that of the water extract.

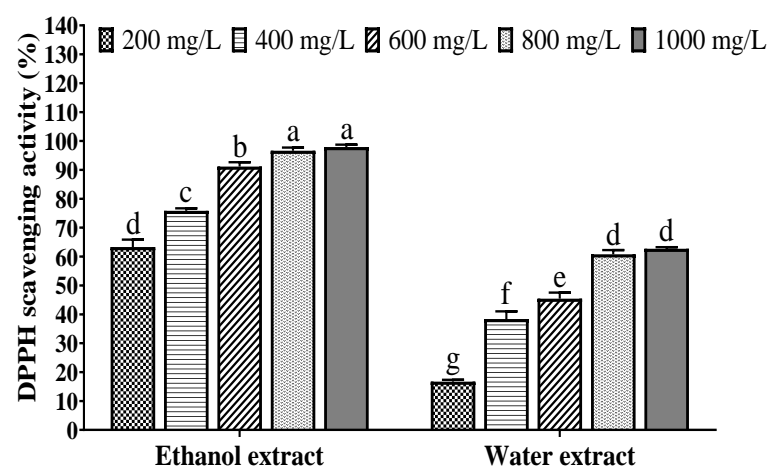

Figure 1. DPPH radical scavenging activities of ethanol and water extracts from $P$. furfuracea (Mean \pm Standard Deviation, $n=3$ ) (Values indicated by different letters differ from each other at the level of $p<0.05)$.

\subsection{Metal chelating activity of $\boldsymbol{P}$. furfuracea}

In metal chelating activity, a concentration-dependent increase was detected in both ethanol and water extracts. The results of the 800 and $1000 \mathrm{mg} / \mathrm{L}$ concentrations showing the highest activity of both extracts were very close 
to each other and posesses statistically $(p>0.05)$ insignificant difference (Figure 2). Based on the $\mathrm{IC}_{50}$ values, the water extract appears to be more effective than the ethanol extract with a lower value $(860.54$ and $906.34 \mathrm{mg} / \mathrm{L}$, respectively) (Table 2).

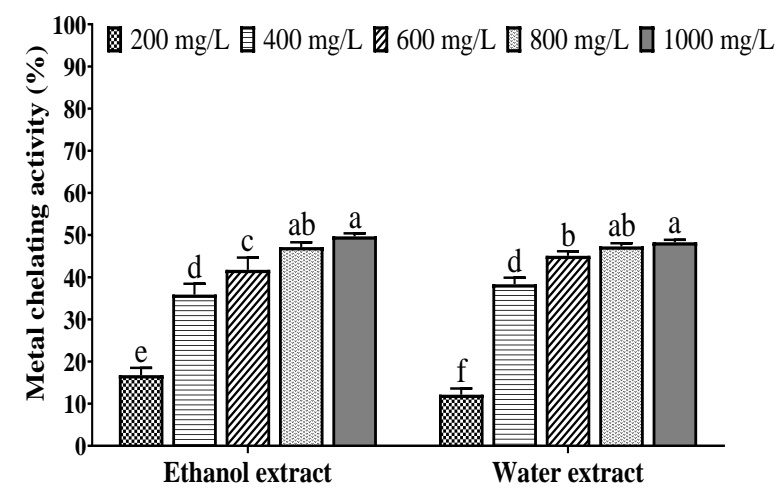

Figure 2. Metal chelating activities of ethanol and water extracts obtained from P. furfuracea (Mean \pm Standard Deviation, $n=3$ ). Values indicated by different letters differ from each other at the level of $p<0.05$.

Table 2. Median inhibitory concentration $\left(\mathrm{IC}_{50}\right)$ values resulting from DPPH scavenging and metal chelating activities of extracts from $P$. furfuracea.

\begin{tabular}{llll}
\hline Activity & Treatment & $\begin{array}{l}\mathbf{I C}_{\mathbf{5 0}} \\
(\mathbf{m g} / \mathbf{L})\end{array}$ & $\begin{array}{l}\text { Slope } \pm \text { Standard error of } \\
\text { the mean (Limits) }\end{array}$ \\
\hline \multirow{2}{*}{$\begin{array}{l}\text { DPPH } \\
\text { scavenging }\end{array}$} & $\begin{array}{l}\text { Ethanol } \\
\text { extract }\end{array}$ & 158.79 & $2.34 \pm 0.17(2.00-2.68)$ \\
\cline { 2 - 4 } & $\begin{array}{l}\text { Water } \\
\text { extract }\end{array}$ & 630.33 & $1.86 \pm 0.14(1.57-2.14)$ \\
\hline \multirow{2}{*}{$\begin{array}{l}\text { Metal } \\
\text { chelating }\end{array}$} & $\begin{array}{l}\text { Ethanol } \\
\text { extract }\end{array}$ & 906.34 & $1.32 \pm 0.14(1.04-1.60)$ \\
\cline { 2 - 4 } & $\begin{array}{l}\text { Water } \\
\text { extract }\end{array}$ & 860.54 & $1.49 \pm 0.14(1.20-1.78)$ \\
\hline
\end{tabular}

\subsection{Analysis of antioxidant compounds of $P$. furfuracea}

Total phenol, $\beta$-carotene, and lycopene contents were investigated from the extracts obtained from $P$. furfuracea. Total phenolic contents were calculated based on the gallic acid equivalent that we used as a standard. The total phenolic amounts of ethanol and water extracts were 71.52 $\mu \mathrm{g} / \mathrm{mg}$ gallic acid equivalent and $8.16 \mu \mathrm{g} / \mathrm{mg}$ gallic acid equivalent, respectively. According to these results, ethanol extract had a higher rate of phenolic compounds compared to the water extract. Likewise, when we look at the $\beta$ carotene and lycopene contents, it was seen that ethanol extracts had higher $\beta$-carotene and lycopene contents compared to water extracts (Table 3 ).

Table 3. Antioxidant compounds of extracts from $P$. furfuracea

\begin{tabular}{lll}
\hline Compound & Treatment & Content $(\boldsymbol{\mu g} / \mathbf{m g})$ \\
\hline $\begin{array}{l}\text { Total phenol } \\
\text { (Gallic acid equivalent) }\end{array}$ & Ethanol extract & $71.52 \pm 2.68$ \\
\hline \multirow{2}{*}{-carotene } & Water extract & $8.16 \pm 0.49$ \\
\hline \multirow{2}{*}{ Lycopene } & Ethanol extract & $0.66 \pm 0.03$ \\
& Water extract & $0.27 \pm 0.01$ \\
\hline & Ethanol extract & $0.32 \pm 0.01$ \\
& Water extract & $0.18 \pm 0.01$ \\
\hline
\end{tabular}

\subsection{The effects of $\mathrm{OA}$ and $\mathrm{PA}$ on expression levels of antioxidant enzymes in THLE2 and HEPG2 cells}

Relative changes in antioxidant enzyme gene expression levels of THLE2 and HepG2 cells were measured by qRTPCR, and the results show the activation of main antioxidant enzymes; cat, gpx, sod1, and sod2, in cancerous HepG2 cells with OA and PA treatments (Figure 3). Similarly, these secondary metabolites also augmented gpx expression in THLE2 cells (Figure 3B). On the contrary to HepG2 cells, OA and PA have suppressive effects on cat, sodl, and sod2 in non-cancerous THLE2 cells (Figure 3A, 3C, and 3D). The results also demonstrated that PA's stimulatory and/or suppressive potential is more than that of $\mathrm{OA}$ at similar concentration and treatment time.

\section{Discussion}

The most widespread type of liver cancer is hepatocellular carcinoma (HCC), the mortality rate of which has increased over the past decade. Among the risk factors, oxidative stress and the reduction in antioxidant capacities might be contributors (Yahya et al., 2013). Even though there are different antioxidant systems to combat the generation of free radicals, the disruption of the balance between pro- and anti-oxidants might lead to oncogenesis and progression of this disease (Cheng et al., 2017).

Under normal circumstances, antioxidant enzymes function to reduce pathologies associated with oxidative stress (Sadi and Sadi, 2010), and exogenous antioxidant supplementations might reverse the detrimental effects of the dysregulated antioxidant network (Sadi and Sadi, 2011). Down-regulation of oxido-reductive enzymes functioning in the most important free radical scavenger systems such as CAT, SOD, and GPx are the characteristic pathological hallmark of HCC. Thus, the balance between oxidative stress and the endogenous antioxidant network is shown to impact the malignant progression of cancers (Marra et al., 2011).

Given the association with the oxidative stress and progression of HCC, the use of herbal products having a high antioxidant capacity for therapeutic purposes has become pronounced. Various plant species have been searched to find effective treatments for cancer with fewer side effects.

Numerous phenolic compounds are produced with lichen species such as xanthones, depsides, and depsidones, and a variety of beneficial effects have been determined. Among them, antioxidant, antiviral, antimicrobial, antifungal, and anticancer activities draw the attention (Ranković and Kosanić, 2019; Solárová et al., 2020b; Roychoudhury et al., 2021). The production of a great variety of secondary metabolites, many of which only appear in lichens, makes them gain pharmaceutical importance. Herein we determined the antioxidant power of $P$. furfuracea, and a remarkable amount of phenolics, $\beta$-carotene, and lycopene contents, especially in ethanolic extracts, have been found. Because of these compounds, P. furfuracea also provides good radical scavenging and metal-chelating properties. Previous studies demonstrated that methanol, aqueous, and acetone extracts from $P$. furfuracea exerted high reducing power, DPPH, and superoxide anion radical scavenging activities (Kosanić and Rankoví, 2011; Bilgin Sökmen et al., 2012). In a study performed on the methanol extract of $P$. furfuracea, even though a high level of total phenol was 
detected, the antioxidant capacity was found to be low (Odabasoglu et al., 2005). Similar to our results, another study also demonstrated a good correlation between radical scavenging activity and the amount of antioxidant compounds (Aoussar et al., 2017).
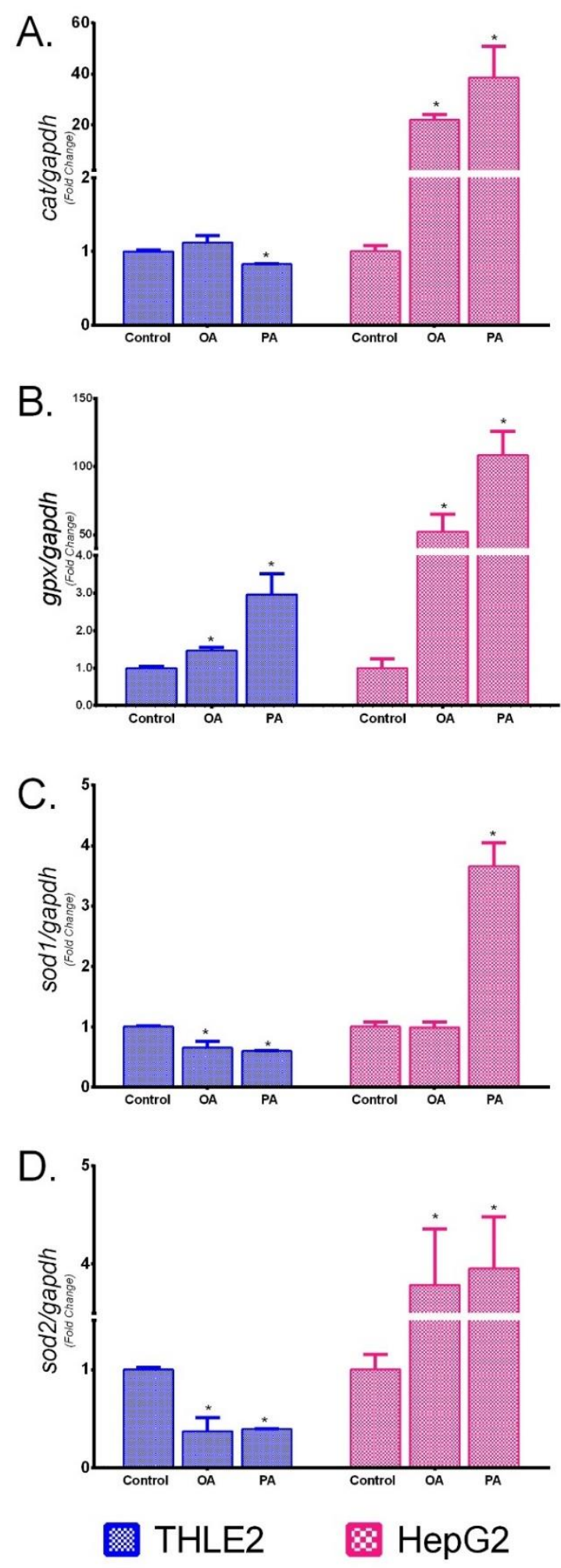

Figure 3. Changes in expression levels of cat (A), gpx (B), sodl (C), and $\operatorname{sod} 2$ (D) mRNA levels in THLE2 and HepG2 cells with $\mathrm{OA}$ and PA treatments. Data were normalized using the data of gapdh. Each bar represents the means from three biological replicates. ${ }^{*} p<0.05$, significantly different from the control; OA: Olivetoric acid; PA: Physodic acid.
In addition to whole extracts of $P$. furfuracea, its isolated secondary metabolites have different antioxidant capacities and biological activities. Physodic acid isolated from $P$. furfuracea had high DPPH and superoxide anion radical scavenging activities (Kosanić et al., 2013). OA and PA isolated from $P$. furfuracea increased the total antioxidant capacity on primary rat cerebral cortex cells (Emsen et al., 2016), human amnion fibroblasts (Emsen et al., 2017) and human lymphocytes (Emsen et al., 2018). Recently, we have demonstrated cytotoxic (apoptotic and necrotic), antioxidant, pro-oxidant, genotoxic, and apoptosis-related genes expression modulatory effects of PA and OA which were isolated from $P$. furfuracea. Results also revealed the lower side effects of these metabolites on healthy cells since HepG2 cells' apoptotic and necrotic genes were highly upregulated in HepG2 but not as much in THLE2 cells (Emsen et al., 2020; Emsen et al., 2021). Herein, we further evaluated the modulatory effects of these metabolites on the gene expression profiles of antioxidant enzymes in cancerous and healthy hepatocytes. Accordingly, the gene expressions of the main antioxidant enzymes, cat, gpx, sodl, and sod2, were upregulated in cancerous HepG2 cells with OA and PA treatments. However, OA and PA have suppressive effects on the cat, sodl, and $\operatorname{sod} 2$ in noncancerous THLE2 cells. The results also demonstrated that PA's stimulatory and/or suppressive potential is more than $\mathrm{OA}$ at similar concentration and treatment time. These results suggest that $\mathrm{OA}$ and $\mathrm{PA}$ promote the antioxidant defense system by increasing antioxidant enzyme expression, inhibiting oxidative stress and tumorigenesis in cancer cells. These metabolites could also hinder cancer progression because of the association between oxidative stress and carcinogenesis.

Activating major cellular antioxidant networks with $P$. furfuracea secondary metabolites could help us to understand the pharmacology of lichens secondary metabolites and their possibilities in the treatment of hepatocellular carcinoma. Our previous data showed the inhibition of cancer cell growth with OA and PA but not on non-cancerous cells, and the data in this study indicates the disproportional upregulation of $\operatorname{sod} 1, \operatorname{sod} 2$, cat, and gpx expression and in cancer cells. These two data together might be an evidence for the induction of apoptosis with a redox dependent mechanisms which might, in turn, induces cancer cell apoptosis. Considering all results together, the importance of $P$. furfuracea and its metabolites, $\mathrm{OA}$ and PA, were revealed as an alternative treatment against liver cancer. It not only has high antioxidant potential, but might also reduce oxidative stress in cancer cells by upregulating antioxidant enzymes, which would prevent oncogenesis and tumor progression in liver cancer.

\section{Conflict of interest}

Authors have declared no conflict of interest.

\section{Authors' contributions}

AA collected and identified the lichen samples. NŞ and BE performed the experiments, BE made the statistical analysis and prepared the manucript draft. GS designed the study, organized the research, made critical reviews on manuscript.

\section{Acknowledgment}

The authors would like to thank Karamanoğlu Mehmetbey University Scientific Research Projects Commission for financial support (grant number 21-YL-19). We also thank to Aykut Bostancı for his help in gene expression studies. 


\section{References}

Ameh SJ, Obodozie OO, Inyang US, Abubakar MS, Garba M (2010). Current phytotherapy - A perspective on the science and regulation of herbal medicine. Journal of Medicinal Plants Research 4(2): 72-81.

Aoussar N, Manzali R, Nattah I, Rhallabi N, Vasiljevic P, Bouksaim M, Douira A, Manojlović N, Mellouki F (2017). Chemical composition and antioxidant activity of two lichens species (Pseudevernia furfuracea $\mathrm{L}$ and Evernia prunastri $\mathrm{L}$ ) collected from Morocco. JMES 8(6): 1968-1976.

Bailly C (2021). The traditional and modern uses of Selaginella tamariscina (P.Beauv.) Spring, in medicine and cosmetic: Applications and bioactive ingredients: Medicinal and cosmetic uses of Selaginella tamariscina. Journal of Ethnopharmacology 280: 114444 .

Bharti R, Chopra BS, Raut S, Khatri N (2021). Pueraria tuberosa: A review on traditional uses, pharmacology, and phytochemistry. Frontiers in Pharmacology 11: 582506.

Bilgin Sökmen B, Kinalioğlu K, Aydin S (2012). Antimicrobial and antioxidant activities of Pseudevernia furfuracea (L.) Zopf var. furfuracea and Evernia prunastri lichens collected from Black Sea Region. Gazi University Journal of Science 25(3): 557565.

Cheng S Bin, Liu HT, Chen SY, Lin PT, Lai CY, Huang YC (2017). Changes of oxidative stress, glutathione, and its dependent antioxidant enzyme activities in patients with hepatocellular carcinoma before and after tumor resection. PLoS ONE 12(1): e0170016.

Emsen B (2019). The antioxidant and antigenotoxic potential of Peltigera canina and Umbilicaria nylanderiana based on their phenolic profile. Farmacia 67(5): 912-921.

Emsen B, Aslan A, Togar B, Turkez H (2016). In vitro antitumor activities of the lichen compounds olivetoric, physodic and psoromic acid in rat neuron and glioblastoma cells. Pharmaceutical Biology 54(9): 1748-1762.

Emsen B, Kolukisa AL (2021). Cytogenetic and oxidative effects of three lichen extracts on human peripheral lymphocytes. Zeitschrift Fur Naturforschung Section C-A Journal of Biosciences 76(7-8): 291-299.

Emsen B, Sadi G, Bostanci A, Gursoy N, Emsen A, Aslan A (2021). Evaluation of the biological activities of olivetoric acid, a lichen-derived molecule, in human hepatocellular carcinoma cells. Rendiconti Lincei 32(1): 135-148.

Emsen B, Sadi G, Bostanci A, Aslan A (2020). In vitro evaluation of cytotoxic, oxidative, genotoxic, and apoptotic activities of physodic acid from Pseudevernia furfuracea in HepG2 and THLE2 cells. Plant Biosyst. doi: $10.1080 / 11263504.2020 .1852329$

Emsen B, Togar B, Turkez H, Aslan A (2018). Effects of two lichen acids isolated from Pseudevernia furfuracea (L.) Zopf in cultured human lymphocytes. Zeitschrift Fur Naturforschung Section C-A Journal of Biosciences 73(7-8): 303-312.

Emsen B, Turkez H, Togar B, Aslan A (2017). Evaluation of antioxidant and cytotoxic effects of olivetoric and physodic acid in cultured human amnion fibroblasts. Human \& Experimental Toxicology 36(4): 376-385.

Fu Y, Chung F-L (2018). Oxidative stress and hepatocarcinogenesis. Hepatoma Research 4(8): 39.

Güvenç A, Küpeli Akkol E, Süntar İ, Keleş H, Yıldız S, Çalış İ (2012). Biological activities of Pseudevernia furfuracea (L.) Zopf extracts and isolation of the active compounds. Journal of Ethnopharmacology 144(3): 726-734.

Karabulut G, Ozturk S (2015). Antifungal activity of Evernia prunastri, Parmelia sulcata, Pseudevernia furfuracea var. furfuracea. Pakistan Journal of Botany 47(4): 1575-1579.

Karagöz A, Aslan A (2005). Antiviral and cytotoxic activity of some lichen extracts. Biologia 60(3): 281-286.

Korkmaz AI, Akgul H, Sevindik M, Selamoglu Z (2018). Study on determination of bioactive potentials of certain lichens. Acta Alimentaria 47(1): 80-87.

Kosanić M, Manojlović N, Janković S, Stanojković T, Ranković B (2013). Evernia prunastri and Pseudoevernia furfuraceae lichens and their major metabolites as antioxidant, antimicrobial and anticancer agents. Food and Chemical Toxicology 53: 112-118.

Kosanić M, Rankoví B (2011). Lichens as possible sources of antioxidants. Pakistan Journal of Pharmaceutical Sciences 24(2): 165170.

Marra M, Sordelli IM, Lombardi A, Lamberti M, Tarantino L, Giudice A, Stiuso P, Abbruzzese A, Sperlongano R, Accardo M, Agresti M, Caraglia M, Sperlongano P (2011). Molecular targets and oxidative stress biomarkers in hepatocellular carcinoma: An overview. Journal of Translational Medicine 9.

Mitrović T, Stamenković S, Cvetković V, Radulović N, Mladenović M, Stanković M, Topuzović M, Radojević I, Stefanović O, Vasić S, Čomić L (2014). Platismatia glauca and Pseudevernia furfuracea lichens as sources of antioxidant, antimicrobial and antibiofilm agents. EXCLI Journal 13: 938-953.

Mohammed FS, Günal S, Pehlivan M, Doğan M, Sevindik M, Akgül H (2020). Phenolic content, antioxidant and antimicrobial potential of endemic Ferulago platycarpa. Gazi University Journal of Science 33(4): 670-677.

Mohammed FS, Pehlivan M, Sevindik E, Akgul H, Sevindik M, Bozgeyik I, Yumrutas O (2021). Pharmacological properties of edible Asparagus acutifolius and Asparagus officinalis collected from North Iraq and Turkey (Hatay). Acta Alimentaria 50(1): 136-143.

Odabasoglu F, Aslan A, Cakir A, Suleyman H, Karagoz Y, Bayir Y, Halici M (2005). Antioxidant activity, reducing power and total phenolic content of some lichen species. Fitoterapia 76(2): 216-219. 
Pachi VK, Mikropoulou EV, Gkiouvetidis P, Siafakas K, Argyropoulou A, Angelis A, Mitakou S, Halabalaki M (2020). Traditional uses, phytochemistry and pharmacology of Chios mastic gum (Pistacia lentiscus var. Chia, Anacardiaceae): A review. Journal of Ethnopharmacology 254: 112485.

Purvis OW, Coppins BJ, Hawksworth DL, James PW, Moore DM (1992). The lichen flora of Great Britain and Ireland. In: The Lichen Flora of Great Britain and Ireland. London: Natural History Museum Publications in Association with the British Lichen Society.

Ranković B, Kosanić M (2019). Lichens as a potential source of bioactive secondary metabolites. In: Ranković B (ed) Lichen Secondary Metabolites. Springer, pp 1-29.

Roychoudhury S, Sinha B, Choudhury BP, Jha NK, Palit P, Kundu S, Mandal SC, Kolesarova A, Yousef MI, Ruokolainen J, Slama P, Kesari KK (2021). Scavenging properties of plant-derived natural biomolecule para-coumaric acid in the prevention of oxidative stress-induced diseases. Antioxidants 10(8): 1205.

Sadi G, Sadi Ö (2010). Antioxidants and Regulation of Antioxidant Enzymes by Cellular Redox Status. Turkish Journal of Scientific Reviews 3(2): 95-107.

Sadi G, Sadi Ö (2011). Diyabetik Sıçan Karaciğer Dokularında Oksidatif Hasar Parametrelerinin ve Antioksidan Enzimlerin Değişimleri. Biyolojik Bilimler Araştırma Dergisi 4(3): 14-19.

Šeklić DS, Obradović AD, Stanković MS, Živanović MN, Mitrović TL, Stamenković SM, Marković SD (2018). Pro-apoptotic and antimigratory effects of Pseudevernia furfuracea and Platismatia glauca on colon cancer cell lines. Food Technology and Biotechnology 56(3): 421-430.

Shrestha G, Raphael J, Leavitt SD, St. Clair LL (2014). In vitro evaluation of the antibacterial activity of extracts from 34 species of North American lichens. Pharmaceutical Biology 52(10): 1262-1266.

Solárová Z, Liskova A, Samec M, Kubatka P, Büsselberg D, Solár P (2020a). Anticancer potential of lichens' secondary metabolites. Biomolecules 10(1): 87.

Solárová Z, Liskova A, Samec M, Kubatka P, Büsselberg D, Solár P (2020b). Anticancer Potential of Lichens' Secondary Metabolites. Biomolecules.

Turkez H, Aydin E, Aslan A (2014). Role of aqueous Bryoria capillaris (Ach.) extract as a genoprotective agent on imazalil-induced genotoxicity in vitro. Toxicology and Industrial Health 30(1): 33-39.

Wang C, Zhang H, Liu Q, Qi J, Zhuang H, Gou Y, Wang H, Wang Y (2021). A review of the aromatic genus Adenosma: Geographical distribution, traditional uses, phytochemistry and biological activities. Journal of Ethnopharmacology 275: 114075 .

Wirth V (1995). Die Flechten Baden Württembergs. In: Die Flechten Baden Württembergs. Ulmer, Stuttgart, p 1006

Yahya RS, Ghanem OH, Foyouh AAA, Atwa MA, Enany SA (2013). Role of interleukin-8 and oxidative stress in patients with hepatocellular carcinoma. Clinical Laboratory 59(9-10): 969-976.

Zambare VP, Christopher LP (2012). Biopharmaceutical potential of lichens. Pharmaceutical Biology 50(6): 778-798. 